\title{
B1b cells recognize protective antigens after natural infection and vaccination
}

\section{Adam F. Cunningham ${ }^{1}{ }^{*}$, Adriana Flores-Langarica ${ }^{1}$, Saeeda Bobat ${ }^{1}$, Carmen C. Dominguez Medina ${ }^{1}$, Charlotte N. L. Cook ${ }^{1}$, Ewan A. Ross ${ }^{1}$, Constantino Lopez-Macias ${ }^{2}$ and lan R. Henderson ${ }^{1}$}

\author{
MRC Centre for Immune Regulation, Institute for Microbiology and Infection, School of Immunity and Infection, Institute for Biomedical Research, Medical School, \\ University of Birmingham, Birmingham, UK \\ ${ }^{2}$ Medical Research Unit on Immunochemistry, National Medical Centre "Siglo XXI," Specialties Hospital, Mexican Institute for Social Security (IMSS), \\ Mexico City, Mexico
}

\section{Edited by:}

Catherine Pellat-Deceunynck, Centre National de la Recherche Scientifique, France

\section{Reviewed by:}

Kishore Alugupalli, Thomas Jefferson University, USA

Thierry Defrance, Institut National de la Santé et de la Recherche Médicale, France

\section{*Correspondence}

Adam F. Cunningham, School of Immunity and Infection, University of Birmingham, Edgbaston, Birmingham B15 2TT, UK

e-mail: a.f.cunningham@bham.ac.uk
There are multiple, distinct B-cell populations in human beings and other animals such as mice. In the latter species, there is a well-characterized subset of B-cells known as B1 cells, which are enriched in peripheral sites such as the peritoneal cavity but are rare in the blood. B1 cells can be further subdivided into B1a and B1b subsets. There may be additional B1 subsets, though it is unclear if these are distinct populations or stages in the developmental process to become mature B1a and B1b cells. A limitation in understanding B1 subsets is the relative paucity of specific surface markers. In contrast to mice, the existence of B1 cells in human beings is controversial and more studies are needed to investigate the nature of these enigmatic cells. Examples of B1b antigens include pneumococcal polysaccharide and the $\mathrm{Vi}$ antigen from Salmonella Typhi, both used routinely as vaccines in human beings and experimental antigens such as haptenated-Ficoll. In addition to inducing classical Tdependent responses some proteins are B1b antigens and can induce T-independent (TI) immunity, examples include factor $\mathrm{H}$ binding protein from Borrelia hermsii and porins from Salmonella. Therefore, B1b antigens can be proteinaceous or non-proteinaceous, induce TI responses, memory, and immunity, they exist in a diverse range of pathogenic bacteria, and a single species can contain multiple B1b antigens. An unexpected benefit to studying $\mathrm{B} 1 \mathrm{~b}$ cells is that they appear to have a propensity to recognize protective antigens in bacteria. This suggests that studying B1b cells may be rewarding for vaccine design as immunoprophylactic and immunotherapeutic interventions become more important due to the decreasing efficacy of small molecule antimicrobials.

Keywords: B1b cells, antibody responses, bacterial infections, vaccines, B-cells

\section{THE IMPORTANCE OF B-CELLS IN VACCINATION}

B-cells carry a unique signature through the expression of a distinct surface immunoglobulin receptor. Under favorable circumstances, if the cognate antigen is engaged and appropriate secondary signals are received, the B-cell can differentiate into a plasma cell and secrete antibody through at least two pathways $(1,2)$. Depending upon the specificity, antibody can help prevent infections from establishing and protecting against a number of infectious diseases. B-cells can have additional activities during infection, which are not necessarily related to antibody production, where they provide signals through contact-dependent and -independent mechanisms as seen during experimental infections with the helminth Nippostrongylus brasiliensis (3). Such antibodyindependent activities of B-cells are clearly important in infectious and non-infectious diseases (4-6). Thus, B-cells are important modulators of the host response and the growing and extending interest in the effector activities of B-cells is a welcome expansion of our understanding of the activities of this cell type.

Nevertheless, it is the antibody-mediated effector functions of B-cells that are estimated to save $>2$ million lives yearly (7). Antibody is behind the elimination of smallpox and the drastic reductions in the prevalence of measles, polio, diphtheria, tetanus, and a plethora of other infections for which vaccines exist, bringing tremendous economic and social benefits (8). Moreover, once infections have been encountered and natural immunity acquired, then the levels of antibody often correlate to the levels of protection against reinfection (9). Vaccines and antibody typically protect at the first encounter with a pathogen, usually before clinical signs are apparent and when bacterial numbers are at their lowest. In contrast, antibiotics are used when bacterial burdens are toward their peak and when clinical signs are more prominent. This game of numbers is probably a key reason why antimicrobial resistance is more common than resistance to a vaccine. As we head toward an era where increased resistance means existing antimicrobials will be less efficacious, there will be an increasing reliance on antibody-mediated mechanisms to protect us. To achieve this requires an efficient way to identify protective antigens. This is an important concept as separating out which antigens are protective from those antigens which are not is a timely, complex, and costly process (10). Therefore, understanding how to efficiently identify protective antigenic targets on pathogens will be a valuable tool for the future control of infection. We propose that understanding 
the nature and targets of B1 cells, particularly B1b cells, is one such route for this. In this review, we discuss elements associated with B1 cells and infection, with a major emphasis on the relationship between bacterial antigens and B1b cells. This is in part to maintain a focus in the review, but also because other elements of B1 cell biology, particularly B1a cell biology, such as their development, role in housekeeping functions, and in diseases, such as autoimmunity, have been elegantly reviewed elsewhere in detail (11-36).

\section{THE ROLE OF ANTIBODY IN INFECTIONS AND RESPONSES TO VACCINATION}

Virtually, all vaccines work through the induction of antibody. The key point here is that, in general, antibody needs to be pre-existing at the time of pathogen encounter indicating the importance of inducing a persisting plasma-cell response to maintain this protective blanket of antibody. It is clearly desirable to induce B-cell memory to complement these activities and to augment antibody levels after antigen re-encounter, but responses to vaccination with T-independent (TI) antigens such as purified capsular polysaccharides show that robust memory is not essential for vaccines to work (37). Antibody induced to T-dependent (TD) antigens, such as proteins, is induced in two waves. Initially, after antigen encounter extrafollicular (EF) IgM is induced, which is typically of modest affinity as at the earliest time after antigen encounter, it is not derived from germinal centers (GCs; see below). Slightly later, the first IgG is detected, which increases in affinity with time as the GC makes a greater contribution $(1,2)$. Nevertheless, IgM is normally present with IgG to make a significant contribution to protection (38-42). In mice, the isotype of IgG induced can reflect the nature of the immune response. IgG3 is the dominant switched isotype after TI antigens, whereas IgG1 and IgG2a reflect T helper (Th) 2 and Th1 responses, respectively (38). In vivo, the predominant IgG isotype to a single antigen can vary depending upon the antigenic context in which it is encountered by the immune system (43). A relationship between the direction of Th responses and the direction of IgG switching is less clear in human beings, although some responses are more associated with certain IgG isotypes, for instance IgG2 and IgG4 antibodies are commonly found to LPS O chain and helminths, respectively $(44,45)$.

Multiple experimental models of infection show that IgM is critical for much of the short- and long-term protection afforded after natural infection and that the functional roles of $\operatorname{IgM}$ and IgG are likely to be synergistic $(40,46)$. The high avidity of pentameric IgM means that it is efficient at activating complement, whereas not all IgG isotypes are equally efficient at doing this (47). In response to most infections or proteinaceous vaccines, IgG titers will rise over many weeks, whereas IgM titers typically remain steady or fall. High affinity IgG is not induced by purified capsular polysaccharides (48).

For instance, the value of $\operatorname{IgG}$ has been demonstrated in studies using antibody generated during a natural non-typhoidal Salmonella infection or by an experimental protein vaccine against this infection that can induce TI and TD responses $(46,49)$. In these studies, the consistent observation was that IgG could account for up to $95 \%$ of the protection observed in wild-type (WT) mice, although surprisingly the additional benefit of IgG was not necessarily related to it being of high affinity. However, the role of IgG in the absence of IgM was not assessed in these studies. An additional consideration is that cell-free, antibodydependent, complement-mediated bactericidal killing in mice may not be equally active against all infections. This is notable in Salmonella infections, where mouse serum is not effective at killing the organisms in bactericidal assays in vitro as human serum is, and so the true value of IgM and antibody per se may be underrepresented in murine systems (50). A further consideration is that the amount of antibody induced to a single antigen can affect outcome. Individuals with HIV/AIDS have a known increased susceptibility to invasive non-typhoidal Salmonella infections (51). The reason for this was recently attributed to elevated titers of inhibitory IgG to LPS and removal of this antibody enabled bacterial killing by the remaining non-inhibitory antibodies (52). A similar observation has been made in patients with bronchiectasis and a Pseudomonas aeruginosa infection (53). A proportion of these patients have markedly elevated titers of IgG2 to LPS O chain that inhibits cell-free or cell-dependent killing of bacteria. Therefore, efficient protection after infection or vaccination requires antibody to selective targets, present in the right amount and of the right isotype.

\section{THE DEVELOPMENT OF ANTIBODY RESPONSES TO T-DEPENDENT AND INDEPENDENT ANTIGENS}

There are classically three types of antigens (54-56). Some, such as LPS, can act as TI type I antigens, which induce specific and non-specific antibody responses through direct stimulation of the B-cell. A second class of antigens is TI type II antigens. Antigens that fall into this group include purified capsular polysaccharide vaccines such as those generated from pneumococcus and the experimental antigen, haptenated Ficoll. Typical haptens include 4-hydroxy-3-nitrophenyl acetyl (NP) and variations of this such as DNP and TNP. A feature of TI-II antigens is that within a single molecule, there are multiple repeats of the same epitope. This means that there is spatial co-localization of the same epitope and when a B-cell encounters the antigen, then multiple surface $\mathrm{B}$-cell receptors are engaged in parallel (57). This drives a strong signaling response within the cell and abrogates the necessity for T-cell support to generate an antibody response. The third class of antigens is TD antigens, which are generally proteins. This is then processed and presented to T-cells via MHCII to enable their recruitment into the response. Conjugation of a TI-II antigen to a protein carrier can convert it into a TD antigen, a process that typically requires physical linkage $(58,59)$. The consequences of $\mathrm{T}$-cell involvement in the generation of antibody responses are dramatic, since it ultimately results in the induction of productive GCs and the generation of greater amounts of switched antibody of a higher affinity and the generation of robust long lived and memory B-cell responses. Furthermore, conjugating a TI antigen to a protein carrier enables responses to capsular polysaccharide vaccines to be induced in certain groups, such as infants, in whom responses would otherwise be refractory $(60,61)$. The concept of classes of antibody responses has been the focus of recent discussion (62). This has led to the development of the idea of a TI-III response, which displays unique features, as well as sharing some with other types of B-cell responses. The distinct 
features of the TI-III response focus on the support provided by additional bone marrow-derived cells including neutrophils, monocytes, mast cells, and basophils and are induced after infection with bloodborne or gut bacteria. They result in the production of EF antibody and show a marked dependence on TLR signaling for their development.

In mice, responses to model TI-2 and TD alum-precipitated antigens such as NP-chicken gamma globulin or ovalbumin, the kinetics of the immune response has been well characterized for both primary and recall responses and below is a short synopsis based on this non-exhaustive list of references (1, 2, 63-69) (Figure 1). It is likely most of the core features of this response reflect what happens in human beings. After antigen encounter, dendritic cells within the T-zone present and prime T-cells within the first $24 \mathrm{~h}$ to enable their rapid differentiation to $\mathrm{T}$ follicular helper (Tfh) cells. The dendritic cell subset involved in Tfh priming, Ig switching, and other $\mathrm{T}$ effector functions may not always be the same since different subsets can provide these functions in different sites concurrently. For instance, we have found that after flagellin immunization $\mathrm{CD}_{103}{ }^{+}$dendritic cells prime for IgA and IgG in the mesenteric lymph node but not the spleen, and that after Salmonella infection monocyte-derived dendritic cells help prime for IFN $\gamma$-expression in T-cells but not IgG2a responses (70, 71). In parallel, B-cells that have engaged antigen interact with primed Tfh cells also within the T-zone. Depending upon the signals received, B-cells can essentially have one of the three fates. They can die, or while still in the T-zone start to differentiate and proliferate. A proportion of these cells will migrate to the follicles and with the adequate recruitment of Tfh cells start to form GCs. Other B-cells will migrate to EF sites such as the red pulp of the spleen or the medulla of lymph nodes to generate plasmablasts and ultimately plasma cells. The kinetics are important for this process and so by around 5 days after immunization, an initial wave of short-lived IgM and IgG (predominantly IgG1 in mice) plasma cells is readily detectable in EF sites. These peak by around day 7 before gradually falling over the coming days (72). With slightly delayed kinetics, GCs form within the follicles and contribute the majority of plasma cells by a week or so after immunization. The key points that are applicable to the current discussion are that after proteinaceous molecules there is a parallel development of $\mathrm{EF}$ and GC responses, and that there is a robust EF switched IgG response.

What is less appreciated is that the process for the generation of responses to TI-II antigens is similar, but with accelerated kinetics. Thus, after antigen encounter, B-cells still migrate through the T-zone and start to proliferate in this site. Furthermore, some Bcells migrate to the follicles to form GCs that abort around the fourth day after immunization as they lack T-cell help to maintain them. Robust EF plasma-cell responses develop with a rapid expansion of the plasmablast population and the immunoglobulin isotypes most commonly detected are IgM and (in mice) IgG3. There are two major consequences of failing to induce Tfh and GC, mainly the longevity of the antibody response is shorter than that commonly seen to protein antigens, and upon reencountering the same antigen, an accelerated and augmented secondary response is absent. This is a significant clinical problem since hyporesponsiveness to a second immunization with a TI-II vaccine is often

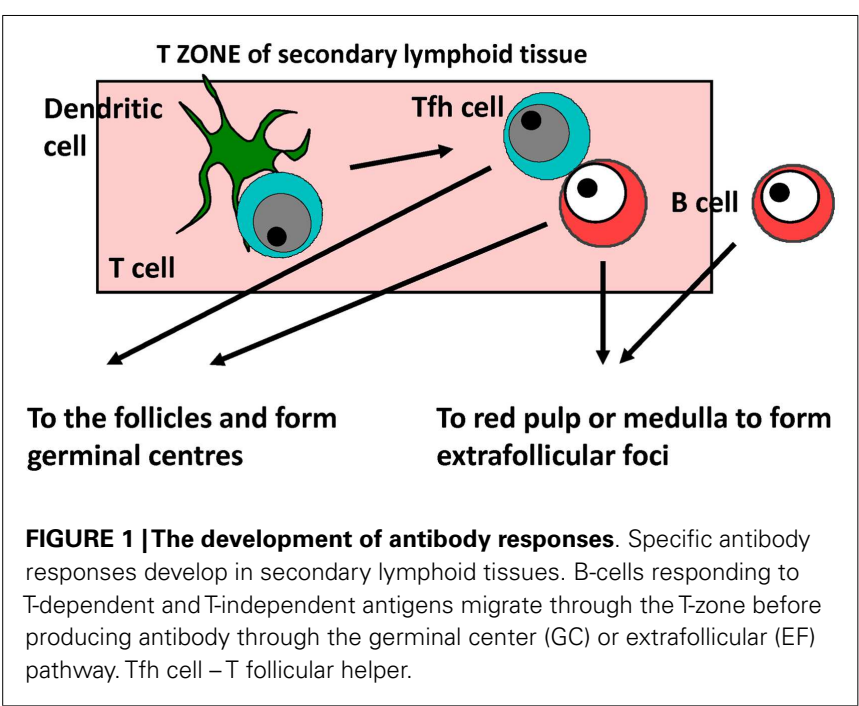

seen. Thus, the mechanics of TD and TI antibody responses show many key similarities.

\section{THE DISTINCT FLAVORS OF B-CELL SUBSETS}

In human beings and mice, there are multiple B-cell subsets, including follicular B-cells and marginal zone (MZ) B-cells, as well as transitional B-cells $(17,31,73-77)$. Follicular and MZ B-cells are known as B2 cells. MZ B-cells contain naïve and antigenexperienced B-cells. Follicular B-cells in both species express IgM, $\operatorname{IgD}$ and are CD $21^{\text {int } / l o}$ and CD $23^{\text {hi }}$. The level of diversity in B-cell receptor usage is greatest in follicular B-cells and accounts for most of the enormous antibody diversity seen in B-cells. Their productive engagement in immune responses shows a clear dependence on T-cells. MZ B-cells also share some similarities between mice and human beings in terms of phenotype with both subsets being $\operatorname{IgM}^{+}, \operatorname{IgD}^{\mathrm{lo} /-}, \mathrm{B} 220^{\mathrm{hi}}, \mathrm{CD} 21^{\text {hi }}$, and CD $23^{\text {lo }}$. Neither B-cell subset has the capacity to self-renew. There are differences between follicular and MZ B-cells. These differences include the sites where they reside, the more limited antigen repertoire recognized by $\mathrm{MZ}$ B-cells, the immaturity of the MZ B-cell compartment after birth, and finally, the capacity of MZ cells to respond to TI-II antigens. These latter two points make the responsiveness of MZ B-cells of significant clinical interest as TI vaccines have poor or negligible efficacy in infants, which correlates with limited MZ B-cell responses.

In mice, there are a number of additional B-cell subsets that are recognized and these come under the umbrella term of B1 cells $(17,22,23,26,28,31,33)$. They are most associated with some serosal sites such as the peritoneal cavity, although they can also be detected in secondary lymphoid tissues and so are probably more widespread than currently appreciated $(78,79)$. A key feature that distinguishes B1 subsets from B2 subsets is their capacity to self-renew. Thus, transfer of B1 populations into lymphopenic mice will result in their expansion over a period of weeks. This means that it is possible to make B1 chimeric mice by transferring peritoneal cells into a Rag-deficient mouse [e.g., Ref. (80)]. In the steady state in the peritoneal cavity of a WT mouse, about $50 \%$ of $\mathrm{B}$-cells are $\mathrm{B} 1$ cells, and we find there is an approximate ratio of $\mathrm{B} 1 \mathrm{a}$ 
cells to B1b cells of $2: 1(46,81)$. A factor that complicates the study of $\mathrm{B} 1$ cells is their more elusive phenotype. They express CD19, low levels of IgD but relatively high levels of IgM. They can express CD43 and CD9, are negative or low expressers for other markers such as CD21 and CD23, and are mostly intermediate for B220 (27, 31, 82-84). In the spleen, many of their characteristics are similar to transitional B-cells when at a transitional T1 stage. Identification of B1a cells is substantially aided by their modest expression of CD5, although in mice expressing CD5 is not necessarily exclusive to B1a cells (85). Another marker closely associated with B1 cells is CD11b, but the frequency of B-cells expressing CD11b can be variable; for instance, during some infections, it alters from that seen during steady-state conditions (46). It is unclear whether the differences in CD11b expression mark distinct B1 subsets or reflect differing developmental stages (86-88). Nonetheless, these factors make examining B1 cells more complicated, particularly in secondary lymphoid tissues, and the often necessary reliance on CD11b as a positive marker, though understandable, is likely to mean their true numbers are underestimated.

\section{EVIDENCE FOR B1 CELLS IN HUMAN BEINGS}

In human beings, the identification of $\mathrm{B} 1$ cells has proven to be a contentious issue (89-94). Part of the reason for this relates to the difficulty in accessing sites such as the peritoneal cavity, where B1 cells are enriched in mice. Nonetheless, currently, there is limited evidence for an exact replication of the murine phenotype for B1 cells in human beings, particularly for B1a cells $(89,91,95,96)$. One report has identified a rare population of $\mathrm{B}$-cells in patients with chronic variable immunodeficiency disease (97) and cells in other non-human primates (NHP) share common B1b markers (98). B-cells in human fetal cord blood and adult blood with a $\mathrm{CD} 20^{+} \mathrm{CD} 27^{+} \mathrm{CD} 43^{+} \mathrm{CD} 70^{-}$phenotype, but with a variable expression of CD5, CD86, IgM, and IgD have been identified as human B1 cells (89). The definition of these cells is not solely based on surface markers as these cells also had other properties associated with $\mathrm{B} 1$ responses. These include (i) the ability to spontaneously secrete IgM antibody to antigens associated with B1 responses such as phosphorylcholine, a known target of Bla-derived antibody in mice and (ii) the ability to readily interact and prime T-cells. Interestingly, the probability of a human B1 cell having either or both properties correlates to its expression of CD11b. Spontaneous IgM secretion is more associated

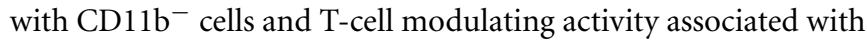
$\mathrm{CD}_{11} \mathrm{~b}^{+}$human $\mathrm{B} 1$ cells. Nevertheless, others have suggested that $\mathrm{CD} 27^{+} \mathrm{CD} 43^{+} \mathrm{CD} 70^{-}$B-cells may reflect a pre-plasmablast differentiation state of cells present in the blood (93). It is tempting to speculate how cumulative exposure to antigen may influence the phenotype and frequency of B1 cells in different species since $\mathrm{B} 1$ cells are more readily detectable in animals kept in controlled environmental conditions. Therefore, currently, there is not a universally accepted definition for B1 cells in human beings as there is for mice.

\section{MICE CONTAIN MULTIPLE B1 SUBSETS}

B1 cells can have phagocytic and antigen-presenting functions, secrete cytokines to modulate the host and produce antibody, with these properties not necessarily mutually exclusive within individual cells $(32,99-101)$. Most work on B1 cells in mice has focused on Bla cells, and their activities have been well reviewed by a number of authors (see above). B1a cells express CD5 and, at least in the steady state, are the dominant B1 subset in the peritoneal cavity. They play a major role in maintaining host immunological tone and homeostasis, but also make striking contributions to the control of infections, such as influenza $(15,31,102,103)$. What is striking about the role of B1a response to influenza is that they contribute antibody through two pathways. The first is through the production of natural antibody, which is generated independent of the presence of cognate antigen. The second is the generation of antibody during infection. Influenza infection results in the accumulation of B1a cells to sites of infection and their production of antibody specific to the pathogen. Bla cells are able to generate IgM and IgA antibodies of modest affinity that can be poly-reactive. Features of the Bla response are atypical since it does not necessarily require the differentiation of B1a cells into CD138-expressing plasma cells or the loss of B1a cell markers, and the majority of the Bla antibody induced is not specific to influenza (104). This suggests a robust early and innate, if "blind" antibody response, which functions to limit infection. While this may simply be a "panic" response to a pathogen, it is also possible that these cells also modulate immunity through phagocytic or contact-dependent mechanisms.

The reported ability of B1a cells to secrete antibody after antigen exposure, but without differentiation into plasma cells, raises questions regarding the nature of antibody-secreting cells. This has only been addressed in any detail for CD5+ B1a cells, and is also an area where reports do not necessarily converge. Based on in vitro, ex vivo, and adoptive transfer studies, Rothstein and colleagues have shown that antibody-secreting B1a cells in the peritoneal cavity show limited expression of genes associated with plasma cells, such as blimp-1 and CD138 (105). Furthermore, IRF4-deficient peritoneal B1 cells can still secrete IgM, whereas splenic B1 cells do not (106). Nevertheless, experiments using Blimp-1 reporter mice failed to support these findings, although Blimp-1-deficient mice retain the capacity to generate some immunoglobulin (107, 108). The differences in these studies may reflect the different approaches taken or other factors. What is lacking is a detailed comparison between plasma cells generated from B-cells of different origins that compare more than the antibody isotype they produce or antigens they initially responded to, although this is clearly a technical challenge.

\section{B1b CELLS MAKE IMPORTANT CONTRIBUTIONS TO PROTECTIVE IMMUNITY IN MICE}

Much of the work examining the activities of B1a cells have focused on their role in autoimmunity, while their roles in controlling infection are less studied. B1a cells do not necessarily function in isolation and, for instance, they can collaborate with B1b cells to combat pneumococcal infections (80). Despite sharing many phenotypic features with Bla cells, such as the generation of natural antibody to self-antigens (109), there are key differences between B1a and B1b cells. There is evidence that each of these cell types has a different developmental pathway and infection may increase a progenitor population that has the potential to generate progeny with a Bla-like phenotype $(26-28,30,31,33,110-116)$. Another 
difference between $\mathrm{B} 1 \mathrm{a}$ and $\mathrm{B} 1 \mathrm{~b}$ cells is that the latter tend to exhibit a greater level of junctional diversity compared to B1a cells suggesting a broader repertoire of antigens is recognized by these cells, although this may be a more complex picture than previously envisaged (117-120). This then leads to a key question. What antigens are recognized by B1b cells and are they clinically relevant?

The first studies showing a potential clinical benefit of B1b responses came from experiments using a murine model of relapsing fever caused by the spirochete Borrelia hermsii $(121,122)$. This bacterial infection in mice results in a pronounced bacteremia, with bacterial numbers reaching $>10^{6-7}$ bacteria/ml blood, but there is much less colonization of tissues by bacteria (123). A key reason for this is the high degree of antigenic variation in certain bacterial surface proteins (124). The infection relapses because antibody develops to the dominant clone and as this is controlled it enables the outgrowth of an antigenically distinct minor clone, which goes on to cause another episode of fever. This can occur multiple times, but typically each further round of bacteremia is less severe than the one that preceded it. This suggests there are protective antigens present that are unrelated to the variable proteins and that the antibody response to these protective antigens develops at a slower rate, due to potential reasons such as antigen density or epitope availability. IgG can contribute to protection in this model but an absolute requirement for IgM has been demonstrated (121-123). A role for B1b cells in protection against $B$. hermsii was identified after infection of a range of genetically altered mice (IL7-/- mice that are deficient in follicular B-cells), splenectomized mice, and B-cell chimeric mice (121). Protection was TI and reinfection of T-cell-deficient mice revealed that a TI memory response was induced. Significantly, B1b chimeras generated by transfer of B1b cells from convalescing mice into Rag1-deficient hosts were more efficient at controlling infection than equivalent chimeras generated using naïve B1b cells. This finding of TI memory was reproduced in a separate model involving immunization with a polysaccharide antigen from Enterobacter cloacae (125).

The unequivocal demonstration of a role for B1b cells in controlling this infection raised questions regarding which antigen was the target for this protective antibody. The obvious candidates were the variable surface proteins from this pathogen, which contribute to immune evasion, but this turned out not to be the case. The target of the protective $\mathrm{B} 1 \mathrm{~b}$ antibody was a conserved protein, the Factor $\mathrm{H}$ binding protein ( $\mathrm{fHbp}$ ), and the response to this protein could develop in the absence of T-cells (126). Antibody to fHbp accumulates slowly with time and protection is only achieved when levels of antibody to this antigen reaches a certain level. This is sufficient to explain why each round of bacteremia tends to be less severe than the one before. This is an important finding and the concept it identifies has far reaching implications for understanding protective immunity during natural infection and for vaccinology. It means that targeting cell wall localized immunodominant antigens is not necessarily required to generate immunity to different strains of the same organism. There are manifold forms of fHbp produced by different bacterial genera and these show significant variability at the protein level. This protein is of interest to vaccinologists as it is one of the protective antigens included in the Bexsero vaccine used against group B meningococcus (127). Alugupalli and colleagues extended their findings on fHbp from $B$. hermsii by generating mice with a humanized immune system, so that all B-cells are derived from human progenitors (128). They showed these chimeras generated IgM antibody to $B$. hermsii and to fHbp and that protection was dependent upon B-cells. Although not formally shown, the antibody response in these chimeras is likely to have been induced in a TI manner. This is a landmark study since it demonstrates that human B-cells are capable of generating anti-protein antibody responses in a manner that resembles the process in mice.

Parallels can be observed between B1b cell responses in mice and the B-cell response in other species to TI-II antigens, such as capsular polysaccharides $(78,80)$. Classically, splenic MZ B-cells are associated with the generation of antibody to such antigens, in part because of the poor responses to capsular polysaccharide vaccines observed in asplenic adults and infants, who lack a mature MZ B-cell compartment $(74,129)$. Nevertheless, mice deficient in $\mathrm{MZ}$ B-cells can still make robust responses to TI-II antigens $(78,130)$ so this does not negate the potential for B1b cells to be involved in such responses. Also, B1b cells are detected in the spleen after immunization with TI-II antigens and they can contribute directly or through interactions with MZ B-cells $(131,132)$. Although B1b cells can recognize haptenated Ficoll, the antigen itself is not a natural antigen and it is typically absent from the environment meaning that in the absence of immunization, animals are naïve to it. This has been exploited to identify the presence of cells that phenotypically and functionally resemble B1 (both B1a and B1b cells) in NHP (African green monkeys and cynomolgus monkeys) (98). NHP B1 cells have a similar phenotype to cells in mice and are CD11b ${ }^{\text {hi }}$ forward scatter hi, CD21 $11^{\mathrm{lo} /-}$ and CD19hi and can upregulate CD27 upon antigen encounter. Like B1b cells, in mice, they respond to TNP-Ficoll and produce IgM and IgG but little IgA.

In an earlier pivotal study, Haas and colleagues demonstrated that capsular polysaccharide from Streptococcus pneumoniae is a B1b antigen and that B1b-derived antibody was sufficient to protect against infection (80). Purified pneumococcal polysaccharide is currently used as a vaccine in human beings against these infections and such responses can be long lived $(133,134)$. The response in B-cells also differs depending whether the vaccine is conjugated or not (135). Additional studies using $\alpha-1,3$ dextran from the Gram-negative bacterium E. cloacae have identified B1b cells as the principal reservoir of memory to bacterial polysaccharide antigens (125). Indeed, B1b cells maintain the potential to respond to pneumococcal polysaccharide throughout life (136), with the mechanisms underlying the responsiveness of B1b cells under active investigation (137). Therefore, identifying targets of $\mathrm{B} 1 \mathrm{~b}$ cells may help in developing strategies to improve vaccination against pneumococcus in the elderly, who are disproportionately susceptible to these infections and in whom vaccination with pneumovax has not had a dramatic effect on the incidence of infection (138). It is likely that the number of infections where $\mathrm{B} 1 \mathrm{~b}$ responses are important will expand. For instance, putative evidence suggests that the characteristic response of the organism Ehrlichia muris at least in part involves B1b cells $(40,139)$. Collectively, studies such as those highlighted above show that B1b 
antigens are present in a plethora of bacterial genera of major clinical importance and that these antigens can be key targets of protective immunity.

\section{SALMONELLA INFECTION AS A MODEL TO STUDY B1 b CELLS}

In murine systems, B1b cells can make a significant contribution to protection. Our own work has examined the B-cell response in the Gram-negative bacterium Salmonella enterica serovar Typhimurium (49). Clearance of primary S. Typhimurium infections in mice requires an intact and persisting CD4 T-cell response regulated by the transcription factor T-bet (140-144). Antibody can protect against secondary infection or after immunization $(46,81,145,146)$. We came to study S. Typhimurium indirectly as a development of our use of model antigens such as ovalbumin and the bacterial TLR5 ligand flagellin (43, 147). Using these antigens, we could show how altering the context in which an antigen was encountered could significantly alter the T- and B-cell response to it. Through immunohistological examination of the splenic plasma-cell response after systemic $S$. Typhimurium infection, we noted that the response was highly atypical (Figure 2). In particular, we noted that the bacterium induced a rapid EF plasmablast response (49). On day 3 after $S$. Typhimurium, the majority of IgM plasmablasts in the red pulp were in cell cycle, and their numbers had already increased $>10$-fold. In parallel, on day 3, there was also a 3-4-fold increase in IgG2a-switched plasmablast numbers, rising to around 20 -fold higher by day 4 , when most IgG2a cells are in cell cycle. In contrast to EF responses after immunization with alum-precipitated proteins (148), the induction of the IgM response was CD40L-independent, whereas switching was CD40L dependent [(49); data not shown]. Atypically, the EF IgM and IgG response in WT mice occurred in the absence of a detectable GC response, which was not observed until the infection was largely cleared (around day 35 in the described model). Therefore, for at least 3 weeks, this model allows the assessment of an EF response in the absence of a confounding influence from GC.

The speed and extent of the EF response and the T-cell independence of its induction had two major implications. First is that there is a significant availability of antigen for B-cells to access, despite the organism having an intracellular life-style and only inducing a low grade bacteremia. Second, it suggests there is likely to be a significant precursor B-cell pool that is enriched for antigens present within this bacterium. Identifying which antigens were targets of the atypical B-cell response was greatly aided by the characterization of the prolonged antibody response to the major porin proteins from S. Typhi OmpF and OmpC. Work by Lopez-Macias, Isibasi and colleagues showed that immunization of human beings and mice with purified, soluble porins induced long-lived bactericidal antibody against typhoid $(149,150)$. These proteins were good candidates as targets of the EF antibody response in that they naturally share features of TI-II antigens such as existing as oligomers and thereby containing repeating epitopes (151). Immunization with purified porin proteins from $S$. Typhimurium showed that these proteins induced a TI response and induced protective antibody primarily through the presence of an additional porin, OmpD, which is absent in S. Typhi (46). Characterizing the peritoneal $\mathrm{B}$-cell response to porin proteins and

\section{The atypical antibody response to Salmonella}

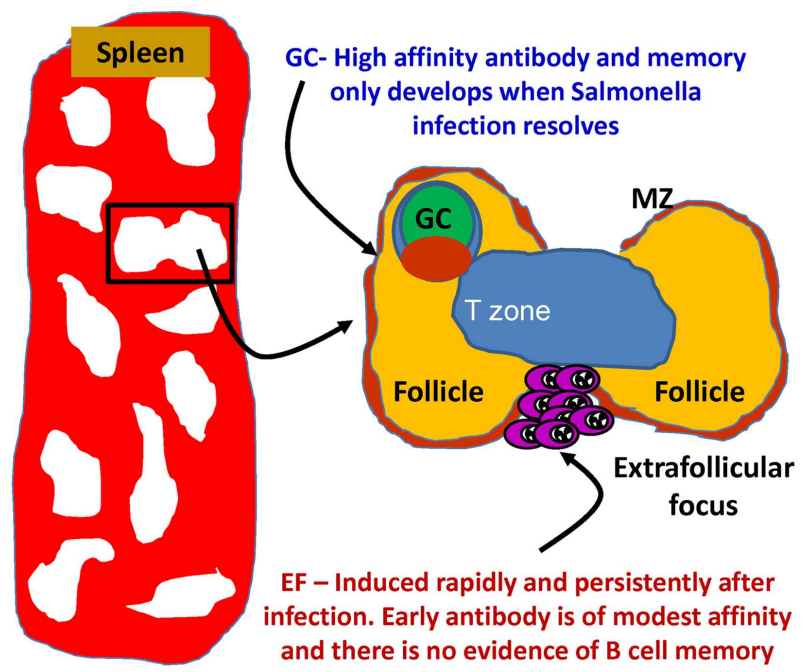

FIGURE 2 |The development of antibody responses in mice after Salmonella infection. After infection, there is a rapid induction of extrafollicular responses, so that $\lg M$ and IgG plasma cells are readily detectable by day 3 . These events occur in the absence of germinal center (GC) responses that are absent until infection has all but cleared. $\mathrm{MZ}$ - marginal zone.

live $S$. Typhimurium showed that both antigens induced a B1b cell response. In contrast, heat-killed bacteria or purified, monomeric flagellin did not. Immunization with TLR grade LPS also induces features of a B1b response, although it is unclear how much of this is antigen-specific or induced through its mitogenic effects. In responses to other Gram-negative bacteria, LPS may induce a B1a response (152). A marker commonly used to help identify $\mathrm{B} 1 \mathrm{~b}$ cells is CD11b. After infection of WT, but not T-cell-deficient mice, the majority of B1b cells was not CD11b+. Thus, it is possible that examination of the response in WT mice using CD11b may under-estimate the numbers of Blb cells, although other reasons may help explain this, such as the maturity of the B1b cells after infection or that additional B1 lineages are recruited to the response.

This model allowed the investigation of other key questions regarding B1b cells, one of which is whether multiple B1b antigens exist within the same species. This was investigated using the $\mathrm{Vi}$ antigen from $S$. Typhi. This antigen, in purified form, is used as a vaccine against typhoid in human beings (146). Since S. Typhi is a human pathogen with limited infectivity in non-primates, it was necessary to examine the response in mice to $S$. Typhimurium engineered to express $\mathrm{Vi}$ antigen and to purified Vi itself $(81,153)$. This allowed a combined approach to be used where the response to $\mathrm{Vi}$ in the context of the bacterium or after immunization with the purified antigen could be examined. These experiments confirmed the TI nature of the response to $\mathrm{Vi}$ and showed that it induced a B1b cell response. Furthermore, the antibody generated by B1b chimeras was sufficient to provide protection against challenge with $S$. Typhimurium expressing Vi. Thus, the same species 


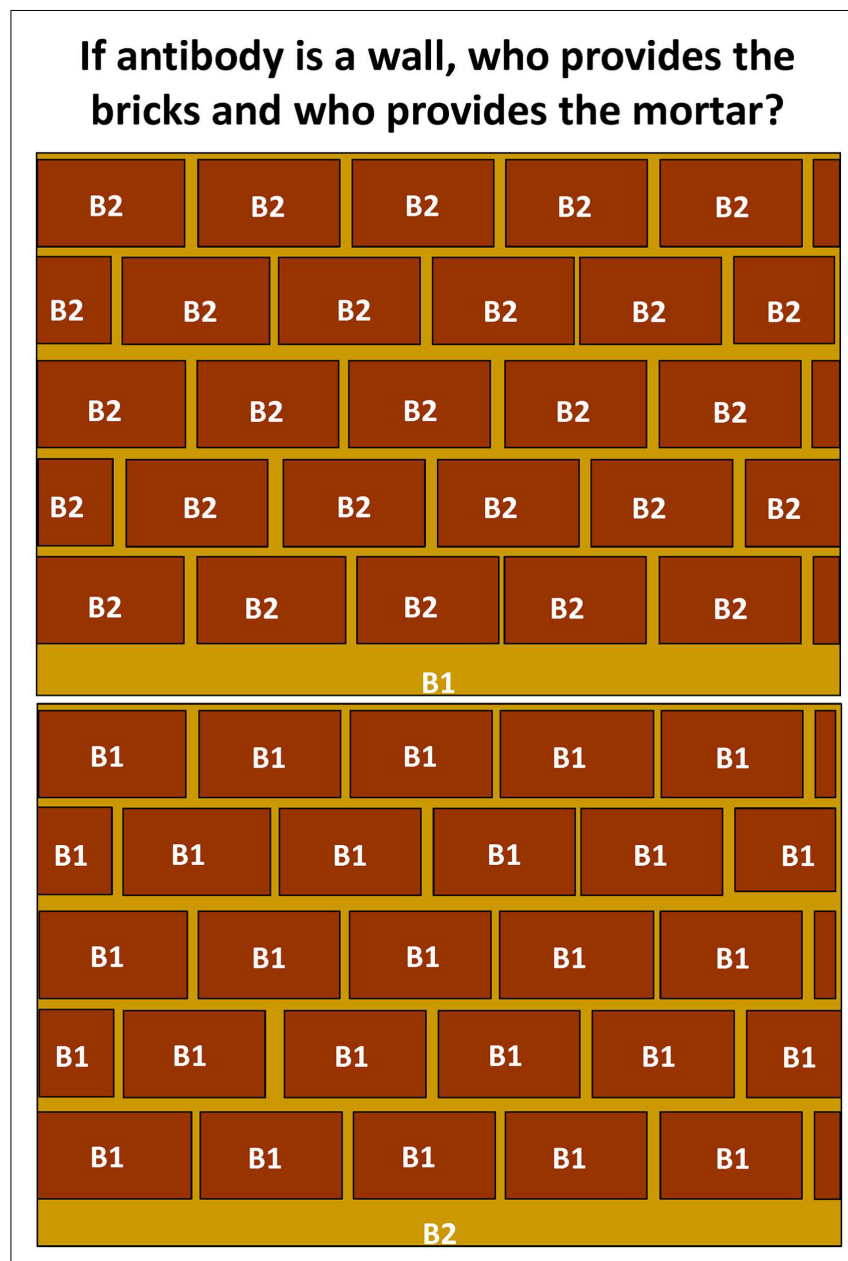

FIGURE 3 |The relative contribution of antibody from B1 and B2 cells Antibody provides a wall of protection against infection. Antibody to many $\mathrm{B} 1$ (b) antigens is also protective and suggests that a wide repertoire of responses are not always necessary to protect against infection. Since antibody to many antigens is not protective, it may be that antibody derived from B1 cells provides greater protection in relative terms than that from B2 cells, particularly follicular B-cells. In the context of this figure, the mortar fills the gaps between the bricks, which provide the majority of protective coverage.

of bacterium contains multiple B1b antigens, suggesting they may be more widely distributed than was perhaps originally perceived when the pioneering studies were being undertaken.

\section{CONCLUSION}

The evidence clearly shows that B1 cells play an important role in providing antibody against infection. Between the B1 subsets, $\mathrm{B} 1 \mathrm{~b}$ cells are most associated with providing responsive antibody during natural infection or after vaccination. The targets of B1b cell-derived antibody appear to have a disproportionate likelihood of also being protective antigens and many of these antigens are known to induce protective responses in human beings. This strongly supports the concept that the $\mathrm{B}$-cell receptor usage by $\mathrm{B} 1 \mathrm{~b}$ cells is not random. Furthermore, the antigens recognized by $\mathrm{B} 1 \mathrm{~b}$ cells are not limited to any one genus or Gram classification. The detection of multiple protective B1b antigens in a single species suggests that B1b antigens are widespread. Therefore, even allowing for the incomplete understanding of B1 responses in human beings examining $\mathrm{B} 1 \mathrm{~b}$ antibody responses in mice is likely to be a rewarding avenue for identifying putative vaccine candidates.

From a personal perspective, there remain a number of unresolved questions regarding the contribution of antibody from and the biology of B1 cells. How complete is our understanding of the nature of selection of B1 cells? How can they be selectively enriched to recognize protective antigens and epitopes? How widespread are B1b cells in human beings? How great is the contribution of antibody from B1b cells to protection after vaccination or natural infection compared to B2 cells and do B1b cells primarily target bacteria and is this restricted to cell wall antigens? Thus, if we think of the protection provided by antibody as a wall then most of a wall is occupied by the bricks, with the gaps between filled by mortar. If antibody to B1b antigens is sufficient to protect against most infections, then the coverage offered by this would be sufficient to protect against the majority of bacterial threats (Figure 3 ). The remaining spaces would be filled by antibodies derived from other B-cell subsets and contribute to protection against antigens such as soluble toxins where there is no evidence of any contribution of B1b cells. How does conjugating a B1b antigen, such as pneumococcal polysaccharide to a typical protein carrier like CRM197, alter the responsiveness of B1b cells to this antigen? Furthermore, how well can B1b cells switch? Experiments using Salmonella show how closely the TI induction of the response and the TD switching in the same response are coupled and so we suspect they are two features of the same B-cell population. Is this really the case or are there two parallel responses induced concurrently? Finally, can B1b cells take part in the GC response? The expansion in the numbers and types of antigens recognized by these cells, the models available, and the intensive investigations underway in human beings make the coming years an exciting time for this field and have implications for both basic and applied immunology, microbiology, and vaccinology.

\section{REFERENCES}

1. MacLennan IC. Germinal centers. Annu Rev Immunol (1994) 12:117-39. doi:10.1146/annurev.iy.12.040194.001001

2. MacLennan IC, Toellner KM, Cunningham AF, Serre K, Sze DM, Zuniga E, et al. Extrafollicular antibody responses. Immunol Rev (2003) 194:8-18. doi:10.1034/j.1600-065X.2003.00058.x

3. Horsnell WG, Darby MG, Hoving JC, Nieuwenhuizen N, McSorley HJ, Ndlovu $\mathrm{H}$, et al. IL-4Ralpha-associated antigen processing by B cells promotes immunity in Nippostrongylus brasiliensis infection. PLoS Pathog (2013) 9:e1003662. doi:10.1371/journal.ppat.1003662

4. Mauri C, Bosma A. Immune regulatory function of B cells. Annu Rev Immunol (2012) 30:221-41. doi:10.1146/annurev-immunol-020711-074934

5. Vadasz Z, Haj T, Kessel A, Toubi E. B-regulatory cells in autoimmunity and immune mediated inflammation. FEBS Lett (2013) 587:2074-8. doi:10.1016/ j.febslet.2013.05.023

6. Dang VD, Hilgenberg E, Ries S, Shen P, Fillatreau S. From the regulatory functions of B cells to the identification of cytokine-producing plasma cell subsets. Curr Opin Immunol (2014) 28C:77-83. doi:10.1016/j.coi.2014.02.009

7. Andre FE. Vaccinology: past achievements, present roadblocks and future promises. Vaccine (2003) 21:593-5. doi:10.1016/S0264-410X(02)00702-8

8. Ehreth J. The global value of vaccination. Vaccine (2003) 21:596-600. doi:10. 1016/S0264-410X(03)00377-3

9. Plotkin SA. Vaccines: correlates of vaccine-induced immunity. Clin Infect Dis (2008) 47:401-9. doi:10.1086/589862 
10. MacLennan CA. Vaccines for low-income countries. Semin Immunol (2013) 25:114-23. doi:10.1016/j.smim.2013.05.004

11. Haughton G, Arnold LW, Whitmore AC, Clarke SH. B-1 cells are made, not born. Immunol Today (1993) 14:84-7. doi:10.1016/0167-5699(93)90064-R discussion 87-91,

12. Kearney JF. CD5+ B-cell networks. Curr Opin Immunol (1993) 5:223-6. doi:10.1016/0952-7915(93)90008-G

13. Arnold LW, Pennell CA, McCray SK, Clarke SH. Development of B-1 cells: segregation of phosphatidyl choline-specific B cells to the B-1 population occurs after immunoglobulin gene expression. J Exp Med (1994) 179:1585-95. doi:10.1084/jem.179.5.1585

14. Baumgarth N. A two-phase model of B-cell activation. Immunol Rev (2000) 176:171-80. doi:10.1034/j.1600-065X.2000.00606.x

15. Baumgarth N, Chen J, Herman OC, Jager GC, Herzenberg LA. The role of B-1 and B-2 cells in immune protection from influenza virus infection. Curr Top Microbiol Immunol (2000) 252:163-9. doi:10.1007/978-3-642-57284-5_17

16. Fagarasan S, Shinkura R, Kamata T, Nogaki F, Ikuta K, Honjo T. Mechanism of B1 cell differentiation and migration in GALT. Curr Top Microbiol Immunol (2000) 252:221-9. doi:10.1007/978-3-642-57284-5_23

17. Fagarasan S, Watanabe N, Honjo T. Generation, expansion, migration and activation of mouse B1 cells. Immunol Rev (2000) 176:205-15. doi:10.1034/j.1600065X.2000.00604.x

18. Hayakawa K, Shinton SA, Asano M, Hardy RR. B-1 cell definition. Curr Top Microbiol Immunol (2000) 252:15-22. doi:10.1007/978-3-642-57284-5_2

19. Herzenberg LA. B-1 cells: the lineage question revisited. Immunol Rev (2000) 175:9-22. doi:10.1111/j.1600-065X.2000.imr017520.x

20. Herzenberg LA, Baumgarth N, Wilshire JA. B-1 cell origins and VH repertoire determination. Curr Top Microbiol Immunol (2000) 252:3-13. doi:10.1007/ 978-3-642-57284-5_1

21. Martin F, Kearney JF. B-cell subsets and the mature preimmune repertoire. Marginal zone and B1 B cells as part of a "natural immune memory". Immunol Rev (2000) 175:70-9. doi:10.1111/j.1600-065X.2000.imr017515.x

22. Martin F, Kearney JF. B1 cells: similarities and differences with other B cell subsets. Curr Opin Immunol (2001) 13:195-201. doi:10.1016/S0952-7915(00) 00204- 1

23. Berland R, Wortis HH. Origins and functions of B-1 cells with notes on the role of CD5. Annu Rev Immunol (2002) 20:253-300. doi:10.1146/annurev. immunol.20.100301.064833

24. Hardy RR, Wei CJ, Hayakawa K. Selection during development of VH11+ B cells: a model for natural autoantibody-producing CD5+ B cells. Immunol Rev (2004) 197:60-74. doi:10.1111/j.0105-2896.2004.0100.x

25. Ha SA, Tsuji M, Suzuki K, Meek B, Yasuda N, Kaisho T, et al. Regulation of B1 cell migration by signals through Toll-like receptors. J Exp Med (2006) 203:2541-50. doi:10.1084/jem.20061041

26. Hardy RR. B-1 B cell development. J Immunol (2006) 177:2749-54. doi:10. 4049/jimmunol.177.5.2749

27. Hardy RR. B-1 B cells: development, selection, natural autoantibody and leukemia. Curr Opin Immunol (2006) 18:547-55. doi:10.1016/j.coi.2006.07.010

28. Montecino-Rodriguez E, Dorshkind K. New perspectives in B-1 B cell development and function. Trends Immunol (2006) 27:428-33. doi:10.1016/j.it.2006. 07.005

29. Tung JW, Herzenberg LA. Unraveling B-1 progenitors. Curr Opin Immunol (2007) 19:150-5. doi:10.1016/j.coi.2007.02.012

30. Barber CL, Montecino-Rodriguez E, Dorshkind K. Developmental relationships between B-1 and B-2 progenitors. Cell Cycle (2011) 10:3810-1. doi:10. 4161/cc.10.22.18190

31. Baumgarth N. The double life of a B-1 cell: self-reactivity selects for protective effector functions. Nat Rev Immunol (2011) 11:34-46. doi:10.1038/ nri2901

32. Gao J, Ma X, Gu W, Fu M, An J, Xing Y, et al. Novel functions of murine B1 cells: active phagocytic and microbicidal abilities. Eur J Immunol (2012) 42:982-92. doi:10.1002/eji.201141519

33. Montecino-Rodriguez E, Dorshkind K. B-1 B cell development in the fetus and adult. Immunity (2012) 36:13-21. doi:10.1016/j.immuni.2011.11.017

34. Sindhava VJ, Bondada S. Multiple regulatory mechanisms control B-1 B cell activation. Front Immunol (2012) 3:372. doi:10.3389/fimmu.2012.00372

35. Baumgarth N. Innate-like B cells and their rules of engagement. Adv Exp Med Biol (2013) 785:57-66. doi:10.1007/978-1-4614-6217-0_7
36. Holodick NE, Rothstein TL. Atypical response of B-1 cells to BCR ligation: a speculative model. Front Immunol (2013) 4:457. doi:10.3389/fimmu.2013. 00457

37. Gonzalez-Fernandez A, Faro J, Fernandez C. Immune responses to polysaccharides: lessons from humans and mice. Vaccine (2008) 26:292-300. doi:10.1016/j.vaccine.2007.11.042

38. Snapper CM, Paul WE. Interferon-gamma and B cell stimulatory factor1 reciprocally regulate Ig isotype production. Science (1987) 236:944-7. doi:10.1126/science. 3107127

39. Winslow GM, Yager E, Li JS. Mechanisms of humoral immunity during Ehrlichia chaffeensis infection. Ann N Y Acad Sci (2003) 990:435-43. doi:10. 1111/j.1749-6632.2003.tb07408.x

40. Racine R, Winslow GM. IgM in microbial infections: taken for granted? Immunol Lett (2009) 125:79-85. doi:10.1016/j.imlet.2009.06.003

41. Racine R, McLaughlin M, Jones DD, Wittmer ST, Macnamara KC, Woodland $\mathrm{DL}$, et al. IgM production by bone marrow plasmablasts contributes to longterm protection against intracellular bacterial infection. J Immunol (2011) 186:1011-21. doi:10.4049/jimmunol.1002836

42. Perez-Shibayama C, Gil-Cruz C, Pastelin-Palacios R, Cervantes-Barragan L, Hisaki E, Chai Q, et al. IFN-gamma-producing CD4+ T cells promote generation of protective germinal center-derived IgM+ B cell memory against Salmonella typhi. J Immunol (2014) 192(11):5192-200. doi:10.4049/jimmunol. 1302526

43. Cunningham AF, Khan M, Ball J, Toellner KM, Serre K, Mohr E, et al. Responses to the soluble flagellar protein FliC are Th2, while those to FliC on Salmonella are Th1. Eur J Immunol (2004) 34:2986-95. doi:10.1002/eji. 200425403

44. Yokota S, Amano K, Hayashi S, Kubota T, Fujii N, Yokochi T. Human antibody response to Helicobacter pylori lipopolysaccharide: presence of an immunodominant epitope in the polysaccharide chain of lipopolysaccharide. Infect Immun (1998) 66:3006-11.

45. Lobos E, Nutman TB, Hothersall JS, Moncada S. Elevated immunoglobulin E against recombinant Brugia malayi gamma-glutamyl transpeptidase in patients with bancroftian filariasis: association with tropical pulmonary eosinophilia or putative immunity. Infect Immun (2003) 71:747-53. doi:10.1128/IAI.71.2.747753.2003

46. Gil-Cruz C, Bobat S, Marshall JL, Kingsley RA, Ross EA, Henderson IR, et al. The porin OmpD from nontyphoidal Salmonella is a key target for a protective B1b cell antibody response. Proc Natl Acad Sci U S A (2009) 106:9803-8. doi:10.1073/pnas.0812431106

47. Dangl JL, Wensel TG, Morrison SL, Stryer L, Herzenberg LA, Oi VT. Segmental flexibility and complement fixation of genetically engineered chimeric human, rabbit and mouse antibodies. EMBO J (1988) 7:1989-94.

48. Toellner KM, Jenkinson WE, Taylor DR, Khan M, Sze DM, Sansom DM, et al. Low-level hypermutation in $\mathrm{T}$ cell-independent germinal centers compared with high mutation rates associated with $\mathrm{T}$ cell-dependent germinal centers. J Exp Med (2002) 195:383-9. doi:10.1084/jem.20011112

49. Cunningham AF, Gaspal F, Serre K, Mohr E, Henderson IR, Scott-Tucker A, et al. Salmonella induces a switched antibody response without germinal centers that impedes the extracellular spread of infection. J Immunol (2007) 178:6200-7. doi:10.4049/jimmunol.178.10.6200

50. Siggins MK, Cunningham AF, Marshall JL, Chamberlain JL, Henderson IR, MacLennan CA. Absent bactericidal activity of mouse serum against invasive African nontyphoidal Salmonella results from impaired complement function but not a lack of antibody. J Immunol (2011) 186:2365-71. doi:10.4049/ jimmunol.1000284

51. Gordon MA. Salmonella infections in immunocompromised adults. J Infect (2008) 56:413-22. doi:10.1016/j.jinf.2008.03.012

52. MacLennan CA, Gilchrist JJ, Gordon MA, Cunningham AF, Cobbold M, Goodall M, et al. Dysregulated humoral immunity to nontyphoidal Salmonella in HIV-infected African adults. Science (2010) 328:508-12. doi:10.1126/ science. 1180346

53. Wells TJ, Withers D, Sevastsyanovich YR, Heath JN, Pravin J, Goodall M, et al. Increased severity of respiratory infections associated with elevated anti-LPS IgG2 which inhibits serum bactericidal killing. J Exp Med (2014) 211(9):1893-904. doi:10.1084/jem.20132444

54. Fagarasan S, Honjo T. T-independent immune response: new aspects of B cell biology. Science (2000) 290:89-92. doi:10.1126/science.290.5489.89 
55. Vos Q, Lees A, Wu ZQ, Snapper CM, Mond JJ. B-cell activation by T-cellindependent type 2 antigens as an integral part of the humoral immune response to pathogenic microorganisms. Immunol Rev (2000) 176:154-70. doi:10.1034/j.1600-065X.2000.00607.x

56. Zubler RH. Naive and memory B cells in T-cell-dependent and T-independent responses. Springer Semin Immunopathol (2001) 23:405-19. doi:10.1007/s281001-8167-7

57. Mond JJ, Lees A, Snapper CM. T cell-independent antigens type 2. Annu Rev Immunol (1995) 13:655-92. doi:10.1146/annurev.iy.13.040195.003255

58. Pollard AJ, Perrett KP, Beverley PC. Maintaining protection against invasive bacteria with protein-polysaccharide conjugate vaccines. Nat Rev Immunol (2009) 9:213-20. doi:10.1038/nri2494

59. Schreiber JR. Role of Toll like receptors in the antibody response to encapsulated bacteria. Front Biosci (Elite Ed) (2012) 4:2638-46. doi:10.2741/E571

60. Adderson EE. Antibody repertoires in infants and adults: effects of Tindependent and T-dependent immunizations. Springer Semin Immunopathol (2001) 23:387-403. doi:10.1007/s281-001-8166-x

61. Landers CD, Chelvarajan RL, Bondada S. The role of B cells and accessory cells in the neonatal response to TI-2 antigens. Immunol Res (2005) 31:25-36. doi:10.1385/IR

62. Vinuesa CG, Chang PP. Innate B cell helpers reveal novel types of antibody responses. Nat Immunol (2013) 14:119-26. doi:10.1038/ni.2511

63. Jacob J, Kelsoe G. In situ studies of the primary immune response to (4hydroxy-3-nitrophenyl)acetyl. II. A common clonal origin for periarteriolar lymphoid sheath-associated foci and germinal centers. J Exp Med (1992) 176:679-87. doi:10.1084/jem.176.3.679

64. Jacob J, Miller C, Kelsoe G. In situ studies of the antigen-driven somatic hypermutation of immunoglobulin genes. Immunol Cell Biol (1992) 70(Pt 2):145-52. doi:10.1038/icb.1992.19

65. Toellner KM, Gulbranson-Judge A, Taylor DR, Sze DM, MacLennan IC. Immunoglobulin switch transcript production in vivo related to the site and time of antigen-specific B cell activation. J Exp Med (1996) 183:2303-12. doi:10.1084/jem.183.5.2303

66. Toellner KM, Luther SA, Sze DM, Choy RK, Taylor DR, MacLennan IC, et al. T helper 1 (Th1) and Th2 characteristics start to develop during T cell priming and are associated with an immediate ability to induce immunoglobulin class switching. J Exp Med (1998) 187:1193-204. doi:10.1084/jem.187.8.1193

67. Garcia de Vinuesa C, O'Leary P, Sze DM, Toellner KM, MacLennan IC. Tindependent type 2 antigens induce B cell proliferation in multiple splenic sites, but exponential growth is confined to extrafollicular foci. Eur J Immunol (1999) 29:1314-23. doi:10.1002/(SICI)1521-4141(199904)29:04<1314::AIDIMMU1314>3.3.CO;2-W

68. Vinuesa CG, Linterman MA, Goodnow CC, Randall KL. T cells and follicular dendritic cells in germinal center B-cell formation and selection. Immunol Rev (2010) 237:72-89. doi:10.1111/j.1600-065X.2010.00937.x

69. Marshall JL, Zhang Y, Pallan L, Hsu MC, Khan M, Cunningham AF, et al. Early B blasts acquire a capacity for Ig class switch recombination that is lost as they become plasmablasts. Eur J Immunol (2011) 41:3506-12. doi:10.1002/eji.201141762

70. Flores-Langarica A, Marshall JL, Bobat S, Mohr E, Hitchcock J, Ross EA, et al. T-zone localized monocyte-derived dendritic cells promote Th1 priming to Salmonella. Eur J Immunol (2011) 41:2654-65. doi:10.1002/eji.201141440

71. Flores-Langarica A, Marshall JL, Hitchcock J, Cook C, Jobanputra J, Bobat $\mathrm{S}$, et al. Systemic flagellin immunization stimulates mucosal CD103+ dendritic cells and drives Foxp3+ regulatory $\mathrm{T}$ cell and IgA responses in the mesenteric lymph node. J Immunol (2012) 189:5745-54. doi:10.4049/ jimmunol.1202283

72. Sze DM, Toellner KM, Garcia De Vinuesa C, Taylor DR, MacLennan IC. Intrinsic constraint on plasmablast growth and extrinsic limits of plasma cell survival. J Exp Med (2000) 192:813-21. doi:10.1084/jem.192.6.813

73. Lopes-Carvalho T, Kearney JF. Development and selection of marginal zone B cells. Immunol Rev (2004) 197:192-205. doi:10.1111/j.0105-2896.2004.0112.x

74. Weill JC, Weller S, Reynaud CA. Human marginal zone B cells. Annu Rev Immunol (2009) 27:267-85. doi:10.1146/annurev.immunol.021908.132607

75. Vaughan AT, Roghanian A, Cragg MS. B cells - masters of the immunoverse. Int J Biochem Cell Biol (2011) 43:280-5. doi:10.1016/j.biocel.2010.12.005

76. Garraud O, Borhis G, Badr G, Degrelle S, Pozzetto B, Cognasse F, et al. Revisiting the B-cell compartment in mouse and humans: more than one B-cell subset exists in the marginal zone and beyond. BMC Immunol (2012) 13:63. doi:10.1186/1471-2172-13-63

77. Pieper K, Grimbacher B, Eibel H. B-cell biology and development. J Allergy Clin Immunol (2013) 131:959-71. doi:10.1016/j.jaci.2013.01.046

78. Hsu MC, Toellner KM, Vinuesa CG, MacLennan IC. B cell clones that sustain long-term plasmablast growth in T-independent extrafollicular antibody responses. Proc Natl Acad Sci U S A (2006) 103:5905-10. doi:10.1073/pnas. 0601502103

79. Colombo MJ, Sun G, Alugupalli KR. T-cell-independent immune responses do not require CXC ligand 13-mediated B1 cell migration. Infect Immun (2010) 78:3950-6. doi:10.1128/IAI.00371-10

80. Haas KM, Poe JC, Steeber DA, Tedder TF. B-1a and B-1b cells exhibit distinct developmental requirements and have unique functional roles in innate and adaptive immunity to S. pneumoniae. Immunity (2005) 23:7-18. doi:10.1016/j.immuni.2005.04.011

81. Marshall JL, Flores-Langarica A, Kingsley RA, Hitchcock JR, Ross EA, LopezMacias C, et al. The capsular polysaccharide Vi from Salmonella typhi is a B1b antigen. J Immunol (2012) 189:5527-32. doi:10.4049/jimmunol.1103166

82. Wells SM, Kantor AB, Stall AM. CD43 (S7) expression identifies peripheral B cell subsets. J Immunol (1994) 153:5503-15.

83. Won WJ, Kearney JF. CD9 is a unique marker for marginal zone B cells, B1 cells, and plasma cells in mice. J Immunol (2002) 168:5605-11. doi:10.4049/ jimmunol.168.11.5605

84. Tung JW, Parks DR, Moore WA, Herzenberg LA. Identification of B-cell subsets: an exposition of 11-color (Hi-D) FACS methods. Methods Mol Biol (2004) 271:37-58. doi:10.1385/1-59259-796-3:037

85. Cong YZ, Rabin E, Wortis HH. Treatment of murine CD5- B cells with anti-Ig, but not LPS, induces surface CD5: two B-cell activation pathways. Int Immunol (1991) 3:467-76. doi:10.1093/intimm/3.5.467

86. Hastings WD, Gurdak SM, Tumang JR, Rothstein TL. CD5+/Mac-1-peritoneal B cells: a novel B cell subset that exhibits characteristics of B-1 cells. Immunol Lett (2006) 105:90-6. doi:10.1016/j.imlet.2006.01.002

87. Ghosn EE, Yang Y, Tung J, Herzenberg LA. CD11b expression distinguishes sequential stages of peritoneal B-1 development. Proc Natl Acad Sci U S A (2008) 105:5195-200. doi:10.1073/pnas.0712350105

88. Hansell CA, Schiering C, Kinstrie R, Ford L, Bordon Y, McInnes IB, et al. Universal expression and dual function of the atypical chemokine receptor D6 on innate-like B cells in mice. Blood (2011) 117:5413-24. doi:10.1182/blood2010-11-317115

89. Griffin DO, Holodick NE, Rothstein TL. Human B1 cells in umbilical cord and adult peripheral blood express the novel phenotype CD20+ CD27+ CD43+ CD70. J Exp Med (2011) 208:67-80. doi:10.1084/jem.20101499

90. Griffin DO, Quach T, Batliwalla F, Andreopoulos D, Holodick NE, Rothstein TL. Human CD11b+ B1 cells are not monocytes: a reply to "gene profiling of $\mathrm{CD} 11 \mathrm{~b}+$ and CD11b- B1 cell subsets reveals potential cell sorting artifacts". J Exp Med (2012) 209:434-6. doi:10.1084/jem.20120403

91. Griffin DO, Rothstein TL. Human b1 cell frequency: isolation and analysis of human b1 cells. Front Immunol (2012) 3:122. doi:10.3389/fimmu.2012.00122

92. Reynaud CA, Weill JC. Gene profiling of CD11b(+) and CD11b(-) B1 cell subsets reveals potential cell sorting artifacts. J Exp Med (2012) 209:433-4. doi:10.1084/jem.20120402

93. Covens K, Verbinnen B, Geukens N, Meyts I, Schuit F, Van Lommel L, et al. Characterization of proposed human B-1 cells reveals pre-plasmablast phenotype. Blood (2013) 121:5176-83. doi:10.1182/blood-2012-12-471953

94. Tangye SG. To B1 or not to B1: that really is still the question! Blood (2013) 121:5109-10. doi:10.1182/blood-2013-05-500074

95. Griffin DO, Rothstein TL. A small CD11b(+) human B1 cell subpopulation stimulates T cells and is expanded in lupus. J Exp Med (2011) 208:2591-8. doi:10.1084/jem.20110978

96. Rothstein TL, Griffin DO, Holodick NE, Quach TD, Kaku H. Human B-1 cells take the stage. Ann N Y Acad Sci (2013) 1285:97-114. doi:10.1111/nyas.12137

97. Rakhmanov M, Keller B, Gutenberger S, Foerster C, Hoenig M, Driessen G, et al. Circulating CD21low B cells in common variable immunodeficiency resemble tissue homing, innate-like B cells. Proc Natl Acad Sci U S A (2009) 106:13451-6. doi:10.1073/pnas.0901984106

98. Yammani RD, Haas KM. Primate B-1 cells generate antigen-specific B cell responses to T cell-independent type 2 antigens. J Immunol (2013) 190:3100-8. doi:10.4049/jimmunol.1203058 
99. Yanaba K, Bouaziz JD, Haas KM, Poe JC, Fujimoto M, Tedder TF. A regulatory $\mathrm{B}$ cell subset with a unique CD1dhiCD5+ phenotype controls T cell-dependent inflammatory responses. Immunity (2008) 28:639-50. doi:10.1016/j.immuni. 2008.03.017

100. Popi AF, Zamboni DS, Mortara RA, Mariano M. Microbicidal property of B1 cell derived mononuclear phagocyte. Immunobiology (2009) 214:664-73. doi:10.1016/j.imbio.2008.12.007

101. Parra D, Rieger AM, Li J, Zhang YA, Randall LM, Hunter CA, et al. Pivotal advance: peritoneal cavity B-1 B cells have phagocytic and microbicidal capacities and present phagocytosed antigen to CD4+ T cells. J Leukoc Biol (2012) 91:525-36. doi:10.1189/jlb.0711372

102. Baumgarth N, Herman OC, Jager GC, Brown L, Herzenberg LA. Innate and acquired humoral immunities to influenza virus are mediated by distinct arms of the immune system. Proc Natl Acad Sci U S A (1999) 96:2250-5. doi:10.1073/pnas.96.5.2250

103. Baumgarth N, Herman OC, Jager GC, Brown LE, Herzenberg LA, Chen J. B-1 and B-2 cell-derived immunoglobulin $\mathrm{M}$ antibodies are nonredundant components of the protective response to influenza virus infection. J Exp Med (2000) 192:271-80. doi:10.1084/jem.192.2.271

104. Choi YS, Baumgarth N. Dual role for B-1a cells in immunity to influenza virus infection. J Exp Med (2008) 2008(205):3053-64. doi:10.1084/jem.20080979

105. Tumang JR, Francés R, Yeo SG, Rothstein TL. Spontaneously Ig-secreting B-1 cells violate the accepted paradigm for expression of differentiation-associated transcription factors. J Immunol (2005) 174:3173-7. doi:10.4049/jimmunol. 174.6.3173

106. Holodick NE, Tumang JR, Rothstein TL. Immunoglobulin secretion by B1 cells: differential intensity and IRF4-dependence of spontaneous IgM secretion by peritoneal and splenic B1 cells. Eur J Immunol (2010) 40:3007-16. doi:10.1002/eji.201040545

107. Fairfax KA, Corcoran LM, Pridans C, Huntington ND, Kallies A, Nutt SL, et al. Different kinetics of blimp-1 induction in B cell subsets revealed by reporter gene. J Immunol (2007) 178:4104-11. doi:10.4049/jimmunol.178.7. 4104

108. Kallies A, Hasbold J, Fairfax K, Pridans C, Emslie D, McKenzie BS, et al. Initiation of plasma-cell differentiation is independent of the transcription factor Blimp-1. Immunity (2007) 26:555-66. doi:10.1016/j.immuni.2007.04.007

109. Ohdan H, Swenson KG, Kruger Gray HS, Yang YG, Xu Y, Thall AD, et al. Mac-1negative B-1b phenotype of natural antibody-producing cells, including those responding to $\mathrm{Gal}$ alpha $1,3 \mathrm{Gal}$ epitopes in alpha 1,3-galactosyltransferasedeficient mice. J Immunol (2000) 165:5518-29. doi:10.4049/jimmunol.165.10. 5518

110. Stall AM, Adams S, Herzenberg LA, Kantor AB. Characteristics and development of the murine B-1b (Ly-1 B sister) cell population. Ann N Y Acad Sci (1992) 651:33-43. doi:10.1111/j.1749-6632.1992.tb24591.x

111. Defrance T, Casamayor-Palleja M, Krammer PH. The life and death of a B cell. Adv Cancer Res (2002) 86:195-225. doi:10.1016/S0065-230X(02)86006-7

112. Montecino-Rodriguez E, Leathers H, Dorshkind K. Identification of a B-1 B cell-specified progenitor. Nat Immunol (2006) 7:293-301. doi:10.1038/ ni1301

113. Dorshkind K, Montecino-Rodriguez E. Fetal B-cell lymphopoiesis and the emergence of B-1-cell potential. Nat Rev Immunol (2007) 7:213-9. doi:10. 1038/nri2019

114. Duber S, Hafner M, Krey M, Lienenklaus S, Roy B, Hobeika E, et al. Induction of $\mathrm{B}$-cell development in adult mice reveals the ability of bone marrow to produce B-1a cells. Blood (2009) 114:4960-7. doi:10.1182/blood-2009-04-218156

115. Ghosn EE, Sadate-Ngatchou P, Yang Y, Herzenberg LA. Distinct progenitors for B-1 and B-2 cells are present in adult mouse spleen. Proc Natl Acad Sci U S A (2011) 108:2879-84. doi:10.1073/pnas.1019764108

116. Ross EA, Flores-Langarica A, Bobat S, Coughlan RE, Marshall JL, Hitchcock JR, et al. Resolving Salmonella infection reveals dynamic and persisting changes in murine bone marrow progenitor cell phenotype and function. Eur J Immunol (2014) 44(8):2318-30. doi:10.1002/eji.201344350

117. Kantor AB, Merrill CE, Herzenberg LA, Hillson JL. An unbiased analysis of $\mathrm{V}(\mathrm{H})-\mathrm{D}-\mathrm{J}(\mathrm{H})$ sequences from B-1a, B-1b, and conventional B cells. J Immunol (1997) 158:1175-86.

118. Holodick NE, Repetny K, Zhong X, Rothstein TL. Adult BM generates CD5+ B1 cells containing abundant N-region additions. Eur J Immunol (2009) 39:2383-94. doi:10.1002/eji.200838920
119. Roy B, Shukla S, Lyszkiewicz M, Krey M, Viegas N, Duber S, et al. Somatic hypermutation in peritoneal B1b cells. Mol Immunol (2009) 46:1613-9. doi:10.1016/j.molimm.2009.02.026

120. Vale AM, Tanner JM, Schelonka RL, Zhuang Y, Zemlin M, Gartland GL, et al. The peritoneal cavity B-2 antibody repertoire appears to reflect many of the same selective pressures that shape the B-1a and B-1b repertoires. J Immunol (2010) 185:6085-95. doi:10.4049/jimmunol.1001423

121. Alugupalli KR, Leong JM, Woodland RT, Muramatsu M, Honjo T, Gerstein RM. B1b lymphocytes confer T cell-independent long-lasting immunity. Immunity (2004) 21:379-90. doi:10.1016/j.immuni.2004.06.019

122. Alugupalli KR. A distinct role for Blb lymphocytes in $\mathrm{T}$ cell-independent immunity. Curr Top Microbiol Immunol (2008) 319:105-30. doi:10.1007/9783-540-73900-5_5

123. Alugupalli KR, Gerstein RM, Chen J, Szomolanyi-Tsuda E, Woodland RT, Leong JM. The resolution of relapsing fever borreliosis requires IgM and is concurrent with expansion of B1b lymphocytes. J Immunol (2003) 170:3819-27. doi:10.4049/jimmunol.170.7.3819

124. Barbour AG. Antigenic variation of a relapsing fever Borrelia species. Annu Rev Microbiol (1990) 44:155-71. doi:10.1146/annurev.mi.44.100190.001103

125. Foote JB, Kearney JF. Generation of B cell memory to the bacterial polysaccharide alpha-1,3 dextran. JImmunol (2009) 183:6359-68. doi:10.4049/jimmunol. 0902473

126. Colombo MJ, Alugupalli KR. Complement factor $\mathrm{H}$-binding protein, a putative virulence determinant of Borrelia hermsii, is an antigenic target for protective B1b lymphocytes. J Immunol (2008) 180:4858-64. doi:10.4049/jimmunol.180. 7.4858

127. Serruto D, Bottomley MJ, Ram S, Giuliani MM, Rappuoli R. The new multicomponent vaccine against meningococcal serogroup B, 4CMenB: immunological, functional and structural characterization of the antigens. Vaccine (2012) 30(Suppl 2):B87-97. doi:10.1016/j.vaccine.2012.01.033

128. Vuyyuru R, Liu H, Manser T, Alugupalli KR. Characteristics of Borrelia hermsii infection in human hematopoietic stem cell-engrafted mice mirror those of human relapsing fever. Proc Natl Acad Sci U S A (2011) 108:20707-12. doi:10.1073/pnas.1108776109

129. Martin F, Kearney JF. Marginal-zone B cells. Nat Rev Immunol (2002) 2:323-35. doi:10.1038/nri799

130. Guinamard R, Okigaki M, Schlessinger J, Ravetch JV. Absence of marginal zone B cells in Pyk-2-deficient mice defines their role in the humoral response. Nat Immunol (2000) 1:31-6. doi:10.1038/76882

131. Martin F, Oliver AM, Kearney JF. Marginal zone and B1 B cells unite in the early response against $\mathrm{T}$-independent blood-borne particulate antigens. Immunity (2001) 14:617-29. doi:10.1016/S1074-7613(01)00129-7

132. Haas KM. Programmed cell death 1 suppresses B-1b cell expansion and longlived IgG production in response to T cell-independent type 2 antigens. $J$ Immunol (2011) 187:5183-95. doi:10.4049/jimmunol.1101990

133. Taillardet M, Haffar G, Mondiere P, Asensio MJ, Gheit H, Burdin N, et al. The thymus-independent immunity conferred by a pneumococcal polysaccharide is mediated by long-lived plasma cells. Blood (2009) 114:4432-40. doi:10.1182/blood-2009-01-200014

134. Defrance T, Taillardet M, Genestier L. T cell-independent B cell memory. Curr Opin Immunol (2011) 23:330-6. doi:10.1016/j.coi.2011.03.004

135. Clutterbuck EA, Lazarus R, Yu LM, Bowman J, Bateman EA, Diggle L, et al. Pneumococcal conjugate and plain polysaccharide vaccines have divergent effects on antigen-specific B cells. J Infect Dis (2012) 205:1408-16. doi:10.1093/infdis/jis212

136. Haas KM, Blevins MW, High KP, Pang B, Swords WE, Yammani RD. Aging promotes $\mathrm{B}-1 \mathrm{~b}$ cell responses to native, but not protein-conjugated, pneumococcal polysaccharides: implications for vaccine protection in older adults. $J$ Infect Dis (2014) 209:87-97. doi:10.1093/infdis/jit442

137. Shriner AK, Liu H, Sun G, Guimond M, Alugupalli KR. IL-7-dependent B lymphocytes are essential for the anti-polysaccharide response and protective immunity to Streptococcus pneumoniae. J Immunol (2010) 185:525-31. doi:10.4049/jimmunol.0902841

138. Jackson LA, Neuzil KM, Yu O, Benson P, Barlow WE, Adams AL, et al. Effectiveness of pneumococcal polysaccharide vaccine in older adults. $N$ Engl J Med (2003) 348:1747-55. doi:10.1056/NEJMoa022678

139. Racine R, Chatterjee M, Winslow GM. CD11c expression identifies a population of extrafollicular antigen-specific splenic plasmablasts responsible for 
CD4 T-independent antibody responses during intracellular bacterial infection. J Immunol (2008) 181:1375-85. doi:10.4049/jimmunol.181.2.1375

140. Ravindran R, Foley J, Stoklasek T, Glimcher LH, McSorley SJ. Expression of Tbet by CD4 T cells is essential for resistance to Salmonella infection. J Immunol (2005) 175:4603-10. doi:10.4049/jimmunol.175.7.4603

141. Gaspal F, Bekiaris V, Kim MY, Withers DR, Bobat S, MacLennan IC, et al. Critical synergy of CD30 and OX40 signals in CD4 T cell homeostasis and Th1 immunity to Salmonella. J Immunol (2008) 180:2824-9. doi:10.4049/jimmunol.180. 5.2824

142. Bobat S, Flores-Langarica A, Hitchcock J, Marshall JL, Kingsley RA, Goodall $\mathrm{M}$, et al. Soluble flagellin, FliC, induces an Ag-specific Th2 response, yet promotes T-bet-regulated Th1 clearance of Salmonella typhimurium infection. Eur J Immunol (2011) 41:1606-18. doi:10.1002/eji.201041089

143. Griffin AJ, McSorley SJ. Development of protective immunity to Salmonella, a mucosal pathogen with a systemic agenda. Mucosal Immunol (2011) 4:371-82. doi:10.1038/mi.2011.2

144. Ross EA, Coughlan RE, Flores-Langarica A, Bobat S, Marshall JL, Hussain K, et al. CD31 is required on CD4+ T cells to promote $\mathrm{T}$ cell survival during Salmonella infection. J Immunol (2011) 187:1553-65. doi:10.4049/jimmunol. 1000502

145. McSorley SJ, Jenkins MK. Antibody is required for protection against virulent but not attenuated Salmonella enterica serovar typhimurium. Infect Immun (2000) 68:3344-8. doi:10.1128/IAI.68.6.3344-3348.2000

146. Guzman CA, Borsutzky S, Griot-Wenk M, Metcalfe IC, Pearman J, Collioud A, et al. Vaccines against typhoid fever. Vaccine (2006) 24:3804-11. doi:10.1016/j.vaccine.2005.07.111

147. Serre K, Mohr E, Toellner KM, Cunningham AF, Granjeaud S, Bird R, et al. Molecular differences between the divergent responses of ovalbumin-specific CD4 T cells to alum-precipitated ovalbumin compared to ovalbumin expressed by Salmonella. Mol Immunol (2008) 45:3558-66. doi:10.1016/j.molimm.2008. 05.010

148. Cunningham AF, Serre K, Mohr E, Khan M, Toellner KM. Loss of CD154 impairs the Th2 extrafollicular plasma cell response but not early $\mathrm{T}$ cell proliferation and interleukin-4 induction. Immunology (2004) 113:187-93. doi:10.1111/j.1365-2567.2004.01951.x

149. Salazar-Gonzalez RM, Maldonado-Bernal C, Ramirez-Cruz NE, Rios-Sarabia N, Beltran-Nava J, Castanon-Gonzalez J, et al. Induction of cellular immune response and anti-Salmonella enterica serovar Typhi bactericidal antibodies in healthy volunteers by immunization with a vaccine candidate against typhoid fever. Immunol Lett (2004) 93:115-22. doi:10.1016/j.imlet.2004.01.010
150. Secundino I, Lopez-Macias C, Cervantes-Barragan L, Gil-Cruz C, Rios-Sarabia $\mathrm{N}$, Pastelin-Palacios R, et al. Salmonella porins induce a sustained, lifelong specific bactericidal antibody memory response. Immunology (2006) 117:59-70. doi:10.1111/j.1365-2567.2005.02263.x

151. Nikaido H. Molecular basis of bacterial outer membrane permeability revisited. Microbiol Mol Biol Rev (2003) 67:593-656. doi:10.1128/MMBR.67.4.593656.2003

152. Cole LE, Mann BJ, Shirey KA, Richard K, Yang Y, Gearhart PJ, et al. Role of TLR signaling in Francisella tularensis-LPS-induced, antibody-mediated protection against Francisella tularensis challenge. J Leukoc Biol (2011) 90:787-97. doi:10.1189/jlb.0111014

153. Jansen AM, Hall LJ, Clare S, Goulding D, Holt KE, Grant AJ, et al. A Salmonella typhimurium-Typhi genomic chimera: a model to study Vi polysaccharide capsule function in vivo. PLoS Pathog (2011) 7:e1002131. doi:10.1371/journal. ppat. 1002131

Conflict of Interest Statement: Adam F. Cunningham has a patent on OmpD - Pub. No.: WO/2010/029293 International Application No.: PCT/GB2009/002159: Non-typhoidal Salmonella vaccines (http://patentscope. wipo.int/search/en/WO2010029293). Granted and currently under license with NVGH and held in South Africa, China, Brazil, Canada, US, and UK. The other co-authors declare that the research was conducted in the absence of any commercial or financial relationships that could be construed as a potential conflict of interest.

Received: 05 June 2014; accepted: 10 October 2014; published online: 31 October 2014. Citation: Cunningham AF, Flores-Langarica A, Bobat S, Dominguez Medina CC, Cook CNL, Ross EA, Lopez-Macias C and Henderson IR (2014) B1b cells recognize protective antigens after natural infection and vaccination. Front. Immunol. 5:535. doi: 10.3389/fimmu.2014.00535

This article was submitted to B Cell Biology, a section of the journal Frontiers in Immunology.

Copyright (c) 2014 Cunningham, Flores-Langarica, Bobat, Dominguez Medina, Cook, Ross, Lopez-Macias and Henderson. This is an open-access article distributed under the terms of the Creative Commons Attribution License (CC BY). The use, distribution or reproduction in other forums is permitted, provided the original author (s) or licensor are credited and that the original publication in this journal is cited, in accordance with accepted academic practice. No use, distribution or reproduction is permitted which does not comply with these terms. 